\title{
The erythrocyte glutathione reductase activity (E.C. 1.6.4.2) of healthy blood donors
}

\author{
M. L. SALKIE AND E. SIMPSON \\ From the Department of Clinical Chemistry, University of Dundee, Scotland
}

SUMMARY The erythrocyte glutathione reductase activity was measured in 199 healthy blood
donors. The normal range was found to be 6.3 to $39.01 \mathrm{U} / 10^{9}$ erythrocytes. There was no
variation related to either age or sex.

The enzyme content of the red blood cell has been well reviewed by Prankerd (1961) and by Pennel (1964). It is now well established that variations in both the content and activity of the erythrocyte enzymes can occur in health (McDonald and Huismann, 1962; Bernard, Dubin, Madec, and le Cam, 1966; (Swierczewski land Gibelin, 1965; Haywood and Starkweather, 1968) and in disease (Bonsignore, Fornaini, Segni, and Fantoni, 1960; Carson, Brewer, and Ickes, 1961 ; Lohr and Waller, 1961; Fornaini, Bianchini, Leoncini, and Fantoni, 1964; Loder and de Gruchy, 1965; Beutler, 1968; Grimes, 1969; Necheles, Maldonado, Barquet Chediak, and Allen, 1969).

The present study of erythrocyte glutathione reductase activity was carried out to develop a reliable, rapid assay method and to use it to find the normal range expressed in units related to the red cell mass. Pennel (1964) quotes normal ranges obtained under differing conditions of temperature, $p \mathrm{H}$, substrate concentration, and time of incubation. The values quoted may be related to haemoglobin concentration, haematocrit, or red cell count. In practice, comparison of results obtained by different methods is not satisfactory and there is also little information available as to the relevance of age or sex.

In order to obtain a statistically significant number of results the enzyme activity was assayed in 199 healthy blood donors and the data were analysed for evidence of variation with age or sex (Table I).

\begin{tabular}{lcccc}
\hline Sex & No. & Mean & $S D$ & $\begin{array}{l}\text { Coefficient } \\
\text { of Variation }\end{array}$ \\
\hline Male & 122 & $19 \cdot 7$ & 6.4 & 32.3 \\
Female & 77 & 18.6 & 6.6 & 35.5 \\
Total & 199 & 19.3 & 6.5 & 33.6 \\
\hline
\end{tabular}

Table I Enzyme activity in 199 blood donors

Although erythrocyte glutathione reductase is active in the presence of either NADH or NADPH it is likely that this activity is due to a single molecular species (Icén, 1967). The method described here uses NADPH and is based on the method of Racker (1955) for the assay of enzyme from baker's yeast and liver.

\section{Reagents}

$10 \cdot 2 \mathrm{M}$ PHOSPHATE BUFFER $p \mathrm{H} 7 \cdot 5$

Dissolve $2.65 \mathrm{~g}$ anhydrous $\mathrm{Na}_{2} \mathrm{HPO}_{4}$ and $0.435 \mathrm{~g}$ 只 $\mathrm{KH}_{2} \mathrm{PO}_{4}$ in water and make up to $100 \mathrm{ml}$.

2 SUBSTRATE SOLUTION

Dissolve $5 \mathrm{mg}$ oxidized glutathione (Boehringer) per $0 \cdot 1 \mathrm{ml}$ water.

Prepare fresh daily.

3 COENZYME SOLUTION

Dissolve $5 \mathrm{mg}$ NADPH (Boehringer) per $1.0 \mathrm{ml}$ water. Prepare immediately before use. 


\section{Method}

Two $\mathrm{ml}$ of blood was collected by venepuncture from healthy blood donors. To avoid the possibility of irregularities due to a diurnal variation all samples were collected at approximately the same time of day and after the donors had been resting. An aliquot was taken for red cell counting on a Coulter counter model ' $D$ ' and $0.2 \mathrm{ml}$ of whole blood was washed twice in $10 \mathrm{ml}$ of $0.15 \mathrm{~N}$ saline. The packed cells were mixed mechanically with $2.0 \mathrm{ml}$ of water and stood at $4^{\circ} \mathrm{C}$ for at least 15 minutes. The haemolysate was then centrifuged and $0.2 \mathrm{ml}$ of supernatant used for the enzyme assay.

Tubes containing $2.7 \mathrm{ml}$ of buffer and $0.1 \mathrm{ml}$ of NADPH were incubated for at least three minutes at $25^{\circ} \mathrm{C}$. Then $0.2 \mathrm{ml}$ haemolysate was added and incubated for a further 15 minutes to exhaust any endogenous substrate. The system was then transferred to silica cuvettes with a $1 \mathrm{~cm}$ light path and mixed thoroughly with $0.1 \mathrm{ml}$ substrate. Changes in optical density at $340 \mathrm{~nm}$ were measured in a Unicam S.P. 800 with a slaverecorder, after adjusting the initial optical density to between 0.600 and 0.700 with a suitable blank. Readings were taken for 15 minutes. It was found that the system exhibits a lag phase (Dixon and Webb, 1964) which was not abolished by increasing the concentration of substrate by up to five times. The change of optical density per minute ( $\triangle E / \mathrm{min}$ ) was calculated, therefore, from the gradient obtained after the lag phase, which usually lasted about five minutes.

In order to obtain results directly related to the red cell mass, activity was expressed per $10^{\circ}$ erythrocytes. Since the oxidation of one molecule NADPH corresponds to the reduction of one molecule of oxidized glutathione, the activity in IU is calculated by the equation:

$\frac{\triangle \mathrm{E} / \text { minute } \times 2.5 \times 10^{10}}{\text { Erythrocytes } / \mathrm{mm}^{3}}=\mathrm{IU} / 10^{9}$ erythrocytes.

\section{Results and Discussion}

The normal range was found to be 6.3 to 39.0 $\mathrm{IU} / 10^{9}$ erythrocytes.

The difference between the mean values for males and females was insignificant $(t=1 \cdot 17$, $P>0.05)$ and there was no correlation with age, which varied between 18 years and 63 years.

For the total series, activity would appear to have a skew distribution (Fig. 1) with a range shown in Table II.

The precision of the method over the normal range was shown to be satisfactory by assaying seven specimens in quadruplicate and plotting the standard deviation of the results against their mean (Fig. 2).

\begin{tabular}{cccc}
\hline Percentile & Activity & \\
\hline 5 & 9.5 & \\
10 & 11.4 & \\
25 & 26.9 & 心 \\
90 & 32.0 & \\
95 & &
\end{tabular}

Table II Range of activity

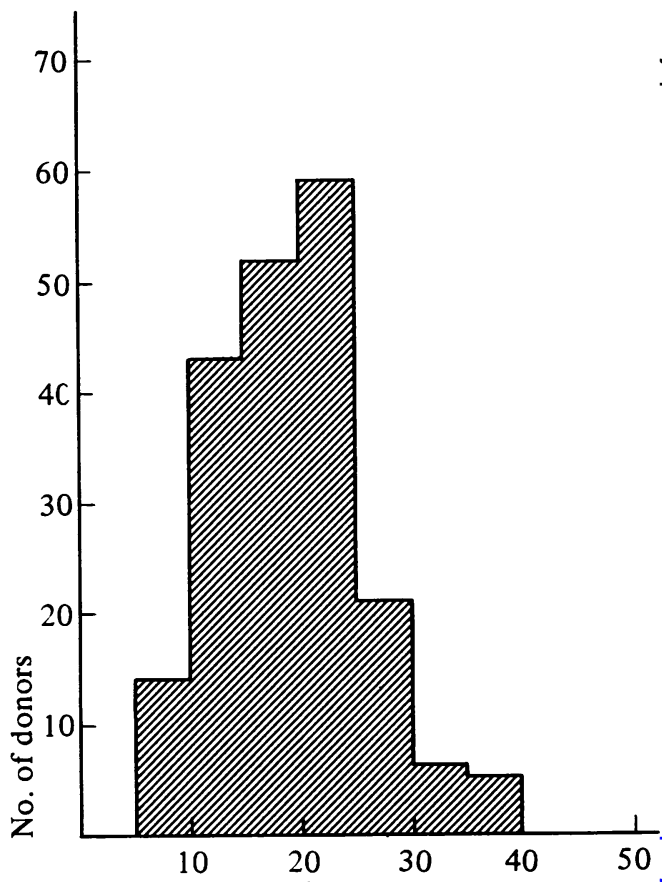

Fig. 1.

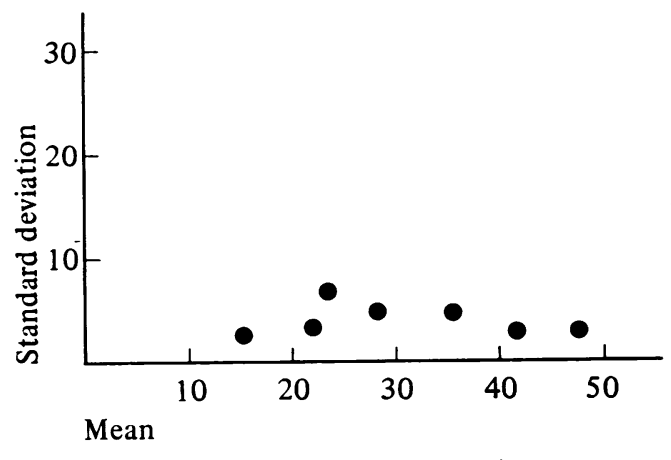

Fig. 2. 
The authors are indebted to Dr C. Cameron, Scottish Blood Transfusion Association, Dundee, for allowing access to blood donors, Dr G. Smith, Maryfield Hospital, Dundee, for arranging the erythrocyte counts, Mr J. Pearson, Department of Social and Occupational Medicine, University of Dundee, for advice and assistance with statistics, and Dr P. E. G. Mitchell, Maryfield Hospital, Dundee, for advice and encouragement.

\section{References}

Bernard, S., Dubin, J. C., Madec, Y., and Le Cam, M. (1966). Sur les variations de quelques activités enzymatiques dans le globule rouge humain, au cours de diverses circonstances physiologiques et pathologiques. Clin. chim. Acta, 14, 300-310.

Beutler,E.(1968). Hereditary Disorders of Erythrocyte Metabolism. Grune and Stratton, New York and London.

Bonsignore, A., Forniani, G., Segni, G., and Fantoni, A. (1960). Glutathione-reductase and methaemoglobin-reductase in erythrocytes of human subjects with a case history of favism. Ital. J. Biochem., 9, 345-353.

Carson, P. E., Brewer, G. J., and Ickes, C. (1961). Decreased glutathione reductase with susceptibility to hemolysis. J. Lab. clin. Med., 58, 804

Dixon, M., and Webb, E. C. (1964). Enzymes. 2nd. ed. Longman, London.

Forniani, G., Bianchini, E., Leoncini, G., and Fantoni, A. (1964). Metabolic aspects of red cells in congenital non-spherocytic haemolytic anaemia. Brit. J. Haemat., 10, 23-35.
Grimes, A. J. (1969). The laboratory diagnosis of enzyme defects in the red cell. Brit. J. Haemat., 17, 129-137.

Haywood, B. J., and Starkweather, W. H. (1968). Diurnale variation of erythrocyte glucose-6-phosphate dehydro-F genase and 6-phosphogluconate dehydrogenase. Amer. J.으 clin. Path., 49, 275-278.

Icén, A. (1967). Glutathione reductase of human erythrocytes Purification and properties. Scand. J. clin. Lab. Invest., 20, Suppl. 96.

Loder, P. B., and de Gruchy, G. C. (1965). Red-cell enzymes anct coenzymes in non-spherocytic congenital haemolytic anaemias. Brit. J. Haemat., 11, 21-31.

Lohr, G. W., and Waller, H. D. (1961a). Biochemie und Patho-震 genese der enzymopenischen hämolytischen Anämien. (I. Teil). Dtsch. med. Wschr., 86, 27-38.

Lohr, G. W., and Waller, H. D. (1961b). Biochemie und Pathogenese der enzymopenischen hämolytischen Anämien $\vec{\circ}$ (II Teil). Dtsch. med. Wschr., 86, 87-93.

McDonald, C. D., Jr., and Huismann, T. H. J. (1962). A com parative study of enzymatic activities in normal adult an cord blood erythrocytes as related to the reduction of methemoglobin. Clin. chim. Acta, 7, 555-559.

Necheles, T. F., Maldonado, N., Barquet, C. A., and Allen, D. M. (1969). Hemozygous erythrocyte glutathionone-peroxidase deficiency: clinical and biochemical studies. Blood, 33,00 164-169.

Pennel, R. P. (1964). In The Red Blood Cell, edited by C. Bishop. 으 Academic Press, New York.

Prankerd, T. A. (1961). The Red Cell. Blackwells, Oxford.

Racker, E. (1955). In Methods in Enzymology, vol. II, edited by S. P. Colowick and N. O. Caplan. Academic Press, New York.

Swierczewski, E., and Gibelin, C. (1965). Glutathion, glutathion réductase, glucose-6-phosphate déshydrogénase dans lę sang de la veine ombilicale et le sang veineux de femmes enceintes. C.R. Acad. Sci. (Paris), 260, 2941-2943. 